\title{
The Contribution of SME to Regional Economic Development: On example of Adjara Autonomous Republic
}

\author{
By Vladimer Glonti ${ }^{1}$, Rezo Manvelidze ${ }^{2}$, Iamze Surmanidze ${ }^{3}$
}

\begin{abstract}
Small and medium entrepreneurship (SME) is one of the most important sectors of the national economy. It determines the economic growth rate of the country/region and the structure of the gross national product. The article aims at evaluating the contribution of SME to the regional economic development on example Adjara A.R. (Republic of Georgia), investigating and analyzing importance of SME development at regional level and discussing the factors influence on its development. In the research section of the given article econometric analyses of SME key indicators is conducted by linear log-regression model based on statistical data of 2006-2019 years. The results of the research study show positive impacts of the number of employees and their productivity on gross value added. The study aims at underlining the government policy supporting an advantageous SME environment and conditions, which is a precondition for regional economic development.
\end{abstract}

Keywords: SME, log-regression model, gross value added, regional development policy

\section{Introduction}

Several researches give evidence that entrepreneurship is an important driver of innovation, productivity growth, competitiveness, economic growth and job creation. the decision makers at regional levels have to give importance to the relationship between entrepreneurial activity and economic development (Schumpeter, Baumol, Aghion, Audretsch, Wennekers and Thurik, Acs, Armington, Bloom, Carlson, Ch. Karlson...).

Small and medium entrepreneurship (SME) is one of the most important sectors of the national economy. It determines the economic growth rate of the country and the structure of the gross national product [Acs...,2002; Audretsch and Thurik, 2002]. On the background of such critical phenomena as unemployment, low revenue and lack of production, SME development helps to solve these problems through the creation of additional job places, through the overcoming of sectorial and territorial monopolies and introducing innovations, many socio-economic problems can be solved in general and reducing [Smallbone, 2001].

SMEs enhances more flexibility to the market economy, mobilizes financial resources of the population, reduces monopoly trends of economics, promotes scientific-technical progress and is an important factor for structural transformations of the economy in general. For Georgia, as for any post-socialist country, it's important development of SME. 
The transition to the market economy has become more actual and the necessary for its development [Chitanava, 2018]. Moreover, in recent decades it has attracted attention from the government. The role and importance of entrepreneurial activities, its problems and actuality has been studied as well in the works of foreign economists (Sherrarden, Hallberg, Demirguç-Kunt...) as by Georgian scientists (Erkomaishvili, Gvelesiani, Mekvabishvili, Chitanava, Tokmazishvili, Asatiani, Pachkoria...). This is the starting point for solving the socioeconomic and social problems of the society, which plays the major role in promoting SME and creating a favorable environment that directly influences the development of SME [Gvelesiani, 1999].

It should be noted that for determining the role of SME in the economic system, it is important to develop regional business, as the country's business sector development is impossible without the business development in its regions [Dvoulety..., 2018]. Region has a strategic role for the economic development, coming from macro and micro perspectives. There is a great need for serious applied research on the benefits of entrepreneurship for regional economic growth analyses. That is why the government policy should be prioritized to expand the existing business potential in the regions and create new opportunities [Tokmazishvili, 2010; Mekvabishvili, 2010].

The experience of developed economies shows that SME development can become a real factor in the stable economy because this sector determines economic growth and the structure of the gross national product. In developed countries SME are developing rapidly, as national governments attach great importance to SME and their assistance. In these countries $50-70 \%$ of GDP has been produced by SMEs in the last few decades.

In developing countries, including Georgia, the largest share of enterprises falls on small and medium enterprises (more than 90\%), but nevertheless their share in the total output is quite low $(<20 \%)$, while in developed countries these figures are much higher, namely the existing enterprises. $99 \%$ are small and medium enterprises and their share exceeds $60 \%$ of the total output ${ }^{1}$.

Many factors influence the economic development of country/region. In this study we will make accent on the entrepreneurial potential of Adjara region (Georgia) ${ }^{2}$, in particular on contribution of small and medium entrepreneurship (SME) to regional economic development.

\section{Overview of Some Economic Indicators Describing Regional Economic and SME Activity in Adjara A.R.}

\subsection{GDP and GVA}

In 2018, GDP of the Autonomous Republic of Adjara (according to current prices) amounted to 4015.6 million GEL, which is 9\% of the country's GDP. The nominal GDP growth of the region amounted to $14 \%$, and GDP per capita amounted to 4556.8 USD (Fig.1).

\footnotetext{
${ }^{1}$ European Commission: Dialogue on «SME Policy» with regard to the multilateral framework of the Eastern Partnership.

${ }^{2}$ Adjara Autonomous Republic is situated to the south-west of Republic of Georgia. Total area: 3 thousand sq.km (4,2 per cent of total area of Georgia); Population: over 400 thousand people ( 82 per cent Georgians); Adjara, as an autonomous region, is the member of the Assembly of European Regions (AER).
} 


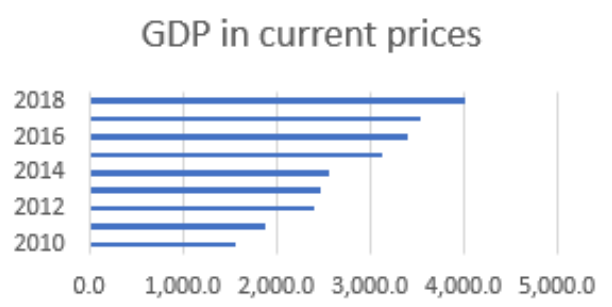

Fig.1 Dynamics of GDP and GVA (Adjara)

Source: National Statistics Office of Georgia

\section{GVA}

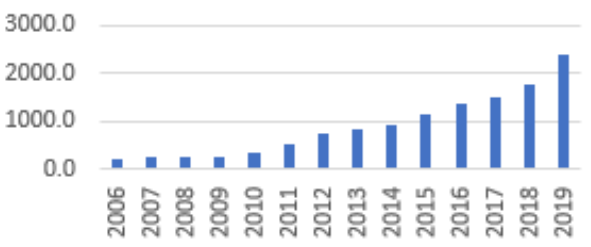

The Gross Added Value (GVA), created in the region, is one of the key benchmarks of regional economic growth. In 2019, GVA (in current prices) of Adjara AR amounted 2382.2 million GEL, which is 10,23\% of Georgia's GVA and 4.8 \% of Georgia's GDP. The share of small enterprises' value added in total country's value was $12.5 \%$ and of medium enterpises- $9.5 \%$.

\subsection{Employment}

The number of employees is an important criterion for MSE activity assessment. According to the regional statistical data (https://www.geostat.ge/regions/), population in Adjara was 351.9 thousand in January 1, 2020. In 2019, economically active population (labor force) was 179.1 thousand, which is $51.3 \%$ of total population of region, while the employed was 163.4 thousand, which is declined by $3.5 \%$ then in the previous year. Accordingly, economic activity rate was $66.7 \%$, the employment rate was $60.8 \%$ and the unemployment rate was $8.8 \%$. It is noteworthy that in recent years, indicators of population activity have worsened and disrupted the growth trend of previous years (table 1).

Table 1. Dynamics of employees in Adjara (thousand persons)

\begin{tabular}{|l|c|c|c|c|c|c|c|}
\hline & $\mathbf{2 0 1 3}$ & $\mathbf{2 0 1 4}$ & $\mathbf{2 0 1 5}$ & $\mathbf{2 0 1 6}$ & $\mathbf{2 0 1 7}$ & $\mathbf{2 0 1 8}$ & $\mathbf{2 0 1 9}$ \\
\hline Total 15 + population & 268,9 & 269,5 & 271,7 & 273,4 & 268,7 & 273,0 & 268,5 \\
\hline Active population (labour force), total & 179,8 & 181,7 & 187,8 & 183,4 & 186,9 & 186,3 & 179,1 \\
\hline Employed & 136,7 & 142,1 & 151,4 & 152,8 & 166,5 & 169,4 & 163,4 \\
\hline Hired & 66,9 & 69,7 & 70,7 & 80,7 & 79,1 & 86,7 & 86,6 \\
\hline Self-employed & 69,7 & 71,9 & 80,5 & 72,1 & 87,3 & 82,6 & 76,8 \\
\hline Not-identified worker & 0,0 & 0,6 & 0,2 & 0,0 & 0,1 & 0,2 & 0,0 \\
\hline Unemployed & 43,2 & 39,6 & 36,4 & 30,6 & 20,4 & 16,9 & 15,7 \\
\hline Population outside labour force & 89,1 & 87,7 & 83,9 & 90,0 & 81,7 & 86,7 & 89,5 \\
\hline Unemployment rate (percentage) & $\mathbf{2 4 , 0}$ & $\mathbf{2 1 , 8}$ & $\mathbf{1 9 , 4}$ & $\mathbf{1 6 , 7}$ & $\mathbf{1 0 , 9}$ & $\mathbf{9 , 1}$ & $\mathbf{8 , 8}$ \\
\hline Economic activity rate (percentage) & $\mathbf{6 6 , 9}$ & $\mathbf{6 7 , 4}$ & $\mathbf{6 9 , 1}$ & $\mathbf{6 7 , 1}$ & $\mathbf{6 9 , 6}$ & $\mathbf{6 8 , 2}$ & $\mathbf{6 6 , 7}$ \\
\hline Employment rate (percentage) & $\mathbf{5 0 , 8}$ & $\mathbf{5 2 , 7}$ & $\mathbf{5 5 , 7}$ & $\mathbf{5 5 , 9}$ & $\mathbf{6 2 , 0}$ & $\mathbf{6 2 , 1}$ & $\mathbf{6 0 , 8}$ \\
\hline
\end{tabular}

Source: National Statistics Office of Georgia

In order to evaluate the business sector economic development, we need to analyze the indicators of the business sector in the region, which reflect the main trends of economic activity of the region. These indicators include the turnover, the production value, number of employees and average monthly remunerations of employees. 
According to the National Statistics Office of Georgia (Geostat), in the II quarter of 2020 the volume of business sector turnover in Adjara, decreased by 40.7 percent than in same quarter of previous year and amounted to 1733.1 million GEL, the production value of the business sector in the II quarter of 2020, equaled to 671.5 million GEL, which is less by 32.5 percent than in same quarter of previous year. According to results of activity of enterprises in the III quarter of 2020 Adjara is leading by the regions in total turnover of business sector after Tbilisi by $5 \%$, in total production value -by $8 \%$, in total number of employees - by $8.6 \%$ [Results of activity...].

For July1 of 2020 year, there were active 18714-unit registered enterprises in business sector of Adjara (35.8\% higher than number in 2018 year), including about 99,7 \% small and medium enterprises defined by new methodology3. Adjara is on the second place according to the turnover and the production value of SME, with share in total value of $10 \%$ and $11 \%$, respectively [Statistical Publication, 2020].

\subsection{Shares of SME in total region business sector}

Concerning the importance role of SMEs in the regional economy, we introduced some economic indicators in total business sector (table 2).

Table 2. Importance of SMEs at regional level

\begin{tabular}{|c|c|c|c|c|c|c|c|}
\hline Year & 2013 & 2014 & 2015 & 2016 & 2017 & 2018 & 2019 \\
\hline Number of Employees of SME (person) & 38436 & 42680 & 44117 & 51140 & 55634 & 56397 & 58218 \\
\hline Number of employees in region & 136668 & 142125 & 151359 & 152797 & 166512 & 169390 & 163379 \\
\hline SMEs employment in total em & $28,1 \%$ & $30,0 \%$ & $29,1 \%$ & $33,5 \%$ & $33,4 \%$ & $33,3 \%$ & $35,6 \%$ \\
\hline Output of SME (mln GEL) & 1314,3 & 1588,9 & 1683,6 & 2145,8 & 2498,6 & 2860,8 & 3071,5 \\
\hline GDP (in current prices) (mln GEL) & 2069,6 & 2371,1 & 2538,4 & 2900,7 & 3367,2 & 4015.6 & $\mathrm{NA}$ \\
\hline SMEs output in re & $63,5 \%$ & $67,0 \%$ & $66,3 \%$ & $74,0 \%$ & $74,2 \%$ & 71.2 & $\mathrm{NA}$ \\
\hline VA of SME & 674,6 & 729,3 & 803,1 & 938,2 & 1205,3 & 1415,7 & 1549,4 \\
\hline GVA of Adjara & 837,4 & 929,3 & 1171,0 & 1368,0 & 1509,7 & 1784,4 & 2382,2 \\
\hline Share of VA in & $81 \%$ & $78 \%$ & $69 \%$ & $69 \%$ & $80 \%$ & $79 \%$ & $65 \%$ \\
\hline
\end{tabular}

Compiled by author; Source of data: National Statistics Office of Georgia

As shown in table, share of SMEs in terms of employment, output and GVA, are quite higher. That proves again that SME has significant place in the regional economy. At the same time, we calculated shares of SME main indicators in total business sector of Adjara A.R. (table 3).

Table 3. Contribution of SME economic indicator as percent in total (Adjara A.R.)

\begin{tabular}{|l|c|c|c|c|c|c|c|}
\hline Year & 2013 & 2014 & 2015 & 2016 & 2017 & 2018 & 2019 \\
\hline Production value & $80,3 \%$ & $77,8 \%$ & $69,4 \%$ & $69,7 \%$ & $79,2 \%$ & $81,0 \%$ & $67,9 \%$ \\
\hline Turnover & $87,5 \%$ & $86,2 \%$ & $74,6 \%$ & $74,9 \%$ & $76,0 \%$ & $79,0 \%$ & $69,4 \%$ \\
\hline Number of employees & $77,2 \%$ & $78,1 \%$ & $76,7 \%$ & $76,8 \%$ & $79,4 \%$ & $80,2 \%$ & $77,8 \%$ \\
\hline
\end{tabular}

Compiled by author; Source of data: National Statistics Office of Georgia

${ }^{3}$ Since 2017 has been changed enterprise size determination methodology: The medium size enterprise with average annual number of employees ranges from 50 to 250 persons, and the average annual turnover is from 12 million GEL to 60 million GEL. The small size of the enterprise - with the average annual number of employees does not exceed 50 employees and the average annual turnover does not exceed 12 million GEL. 
The table shows that high shares of the output, turnover and number of employees in the business sector comes on SME. So, that in the region, SME has much priority.

The evolution of SMEs activity in Adjara A.R. can be describing by the economic indicators of SME sector (table 4).

Table 4. Dynamics of economic indicators of SME sector in Adjara A.R.

\begin{tabular}{|c|c|c|c|c|c|c|}
\hline Year & $\begin{array}{c}\text { Value } \\
\text { Added } \\
\text { (mln.GEL) }\end{array}$ & $\begin{array}{c}\text { Turnover } \\
\text { (mln.GEL) }\end{array}$ & $\begin{array}{c}\text { Production } \\
\text { Value } \\
\text { (mln.GEL) }\end{array}$ & $\begin{array}{c}\text { Number of } \\
\text { Employees } \\
\text { (person) }\end{array}$ & $\begin{array}{c}\text { Investment in } \\
\text { Fixed Assets } \\
\text { (mln.GEL) }\end{array}$ & $\begin{array}{c}\text { Personnel } \\
\text { Costs } \\
\text { (mln.GEL) }\end{array}$ \\
\hline $\mathbf{2 0 0 6}$ & 98,4 & 529,3 & 226,7 & 23731 & 37,9 & 51,5 \\
\hline $\mathbf{2 0 0 7}$ & 140 & 724 & 337,1 & 22650 & 47,4 & 68,3 \\
\hline $\mathbf{2 0 0 8}$ & 167,9 & 828,3 & 402,5 & 21428 & 64,1 & 74,7 \\
\hline $\mathbf{2 0 0 9}$ & 177,6 & 798,9 & 390 & 23390 & 30,9 & 90,8 \\
\hline $\mathbf{2 0 1 0}$ & 228,3 & 959,9 & 500,3 & 24474 & 35,6 & 101,8 \\
\hline $\mathbf{2 0 1 1}$ & 383,2 & 1627,7 & 860,5 & 30365 & 81 & 139,2 \\
\hline $\mathbf{2 0 1 2}$ & 577,1 & 2061,2 & 1256,5 & 35165 & 105,8 & 193,3 \\
\hline $\mathbf{2 0 1 3}$ & 674,6 & 2410,8 & 1314,3 & 38437 & 135,3 & 224,7 \\
\hline $\mathbf{2 0 1 4}$ & 729,3 & 2952,8 & 1588,9 & 42681 & 249,1 & 280,4 \\
\hline $\mathbf{2 0 1 5}$ & 803,1 & 3099,7 & 1683,6 & 44118 & 222,6 & 329,2 \\
\hline $\mathbf{2 0 1 6}$ & 938,2 & 3563,6 & 2145,8 & 51140 & 132,6 & 364,6 \\
\hline $\mathbf{2 0 1 7}$ & 1205,3 & 3935,7 & 2498,6 & 55634 & 451,4 & 461 \\
\hline $\mathbf{2 0 1 8}$ & 1415,7 & 4499,4 & 2860,8 & 56397 & 489,7 & 516,7 \\
\hline $\mathbf{2 0 1 9}$ & 1549,4 & 4258,5 & 3071,5 & 58218 & 648,2 & 620,3 \\
\hline
\end{tabular}

Compiled by author; Source: National Statistics Office of Georgia

The table shows that indicator such value added has increase trend all the time during 2006-2019 years, but the indicators such turnover, production value, number of employees and investment in fixed assets, are decreasing in 2008-2009, which was caused by the August war.

Turnover and production value in recent years has an increasing trend, except 2019 years, when these indicators fall (fig. 2).

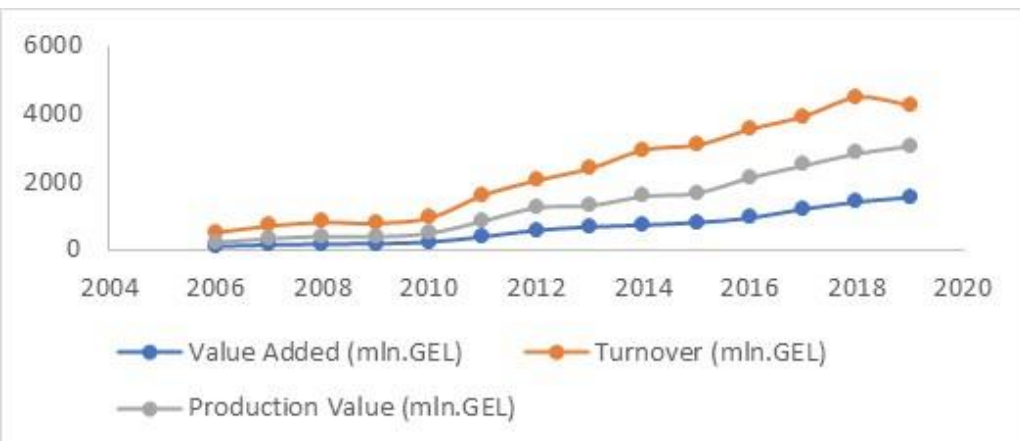

Fig. 2 Production turnover and production value of SME in Adjara for 2006-2019

Compiled by author; Source: National Statistics Office of Georgia 


\section{Data and Methodologies}

At the outset, we agree that the terms "business" and "entrepreneurship" are identified in this article because these two terms are similarly understood in almost all economic dictionaries, although not all scientists do not unify these two in one term. Under the Georgian legislation, "Entrepreneurship" is defined and regulated by the "Law on Entrepreneurs ", although it does not explain the concept of "business"[Law...].

The aim of study is making accent on the SME activity and potential of region, for that purpose we are using indicators listed in table 5 .

\section{Table 5.SME economic indicators and their description}

\begin{tabular}{|l|l|}
\hline Indicator & Description \\
\hline Value-added & $\begin{array}{l}\text { Value added at basic prices in business sector is defined as the value a business } \\
\text { generates from its invested capital. The concept of added value is very important } \\
\text { for businesses, as more value-added lead to increasing revenue. The Gross Value } \\
\text { Added is organic part of GDP created in the regions, which is one of the key } \\
\text { indicators of regional economic growth. Growth of GDP is the sum of increases of } \\
\text { value added in all economic sector. }\end{array}$ \\
\hline Turnover & $\begin{array}{l}\text { Turnover is an indicator of an economic activity during an accounting period. It } \\
\text { corresponds to the volume of sales of enterprises. Turnover is the net sales created } \\
\text { by a business. } \\
\text { Number of persons employed implies (employees, employed shareholders and } \\
\text { employed family members in case of family-owned enterprise) of the company } \\
\text { during reporting period. }\end{array}$ \\
\hline Production & $\begin{array}{l}\text { Output determines quantity of production made by an economic entity, and volume } \\
\text { of realized output including goods or services bought for resale and changes in } \\
\text { stocks of finished goods }\end{array}$ \\
\hline $\begin{array}{l}\text { Number } \\
\text { Employees }\end{array}$ & $\begin{array}{l}\text { Number of employees is defined as persons who work for an enterprise and who } \\
\text { received the salary. Number of persons employed is a different term and implies } \\
\text { employees, employed shareholders and employed family members in case of family- } \\
\text { owned enterprise of the company during reporting period. }\end{array}$ \\
\hline Investment in in Investments in fixed assets includes the purchase and capital improvement of fixed \\
fixed assets & $\begin{array}{l}\text { assets, of which the sales and transfers of fixed assets are deducted. fixed investment } \\
\text { is the accumulation of physical assets such as land, buildings, machinery, technology } \\
\text { etc. }\end{array}$ \\
\hline Personnel & $\begin{array}{l}\text { Labor costs are calculated by summing up all expenses accrued to the staff employed } \\
\text { during the reporting period: Remuneration (salary, allowance, bonus, leave } \\
\text { allowance, compensation payments, etc.) accrued to the staff (in the form of income } \\
\text { tax or income tax). As well as social assistance from the funds of the enterprise, } \\
\text { expenses for education, health, cultural and other aspects). }\end{array}$ \\
\hline
\end{tabular}

Compiled by author; Source: National Statistics Office of Georgia / Methodology for Calculation of key Indicators of Business Statistics /

For evidence the significant contribution of SMEs activity to regional economic development, it's advisable econometric analysis for estimation influence of SME economic indicators on gross domestic product in business sector. First of all, we define representative variables. The gross domestic product may be measured by the production 
value or value added. The SME development strategies often aim at increasing gross value added and not the production value [Cobbold, 2003]. That's why we will choose gross value-added indicator for representative variable of the measure of regional economic development.

Gross Value added is multifactorial indicator, which impact on production factors of and other factors have:

- Labor, that implies human physical and mental effort used in production process. Growth of value added may be as by way increase the number of employees as by labor productivity growth.

- Capital, that implies fixed and working capital used in production process: building, equipment and machinery are one of main factors. More capital leading more production.

- Personnel costs, that are defined as the total remuneration. Personnel Costs includes costs of training programs, hiring expenses, travel expenses, incentive programs and so on. High personnel costs raise motivation and productivity.

- Entrepreneurial skills, which are important for organize factors of production and take risk, make a profit. Right using of resources and organizing production offices is one of important factor of entrepreneurship success.

- Business Environment, Legal and Institutional Framework. Of course, legislation regulations make a business easier and growth the productivity.

- Etc.

Certainly, we cannot determine influence of each, but we can choose some key factors and try estimate their separate impact on gross value-added. About methodology, which helps to construct the model describing the growth rate of gross value added, depends on the focus our study based on economic theory of production function, that gross output defined by production factors (capital and labor) and their productivity. Productivity is considered a key source of economic growth, it represents the amount of output per unit of input and defined as the ratio of outputs (gross domestic product) to inputs (labor and capital) [Coelli..., 2005].

The growth rate of gross value added we can separate into contributions from the growth rate of labor and from the labor productivity growth, last one can measure the employee effectiveness in producing 4 .

Labor productivity represents the total volume of output produced per unit of labor. Labor productivity is often measured by valued added, rather than by production value per unit of employee, which is the more standard measure of labor productivity in economics ${ }^{5}$. The labor productivity is a key economic indicator together with the capital productivity and jointly creates total factor productivity (TFP). In empirical model we have chosen the representative factor of TFP - the employee productivity, as ratio of value added (SME) and number of employees (SME). Of course, labor productivity only partial defines total factor productivity.

\footnotetext{
${ }^{4}$ Measuring Productivity - OECD Economic Studies No. 33, 2001/II

${ }^{5}$ Labor Productivity - ILOSTAT https://www.ilo.org/ilostat-files/Documents/description_PRODY_EN.pdf
} 


\section{Empirical Model}

The main purpose of this paper is analyzing the gross value-added indicator of business sector in Adjara A.R. and identify among the factors listed above affecting factors on its formation and development, so simple linear regression model isn't enough for that. The selection of significant factors is important for constructing the multiple regression model. Factors should be selected according the degree of their impact. The model should take into account factors that have a relatively strong influence on the development of dependent variable. At the same time the small number of observations does not allow us to capture many factors. In order to select the factors for multiple regression, at the first step should to measure linear correlation between the factors, i.e., multicollinearity, which causes a change of parameters estimates in a regression model, changing the economic interpretation of the coefficients and other negative effects. Therefore, should to construct correlation matrix, which is characterized as the degree of correlation between result and factors, as the correlation degree between each factor. Significant and essential factors are those factors, which has more high correlation with result, than with other factors.

Considering all above, we estimated log-linear regression model (because we are interesting the growth rates) with two factors, where the dependent variable is Gross Value Added and the explanatory variables are the number of employees and employee's productivity are all in logarithmic forms. So, the regression model is:

$\ln (\mathrm{GVA})=b_{0}+b_{1}\left(\mathrm{LN} \_\right.$EMPL $)+b_{2}\left(\mathrm{LN} \_\right.$EMPL_PRODUCTIVITY $\left.)\right)+\varepsilon_{i}$

where LN_EMPL denotes natural logarithm of the employees' number, LN_EMPL_PRODUCTIVITY - natural logarithm of the production value per employee. Natural logarithms expressions growth rates of relevant values. $\varepsilon_{i}$ is error term.

The empirical data is based on the time series data, obtained from National Statistics Office of Georgia covering years 2006-2019 (table 4).

\subsection{Interpretation of results}

The estimated log regression model is:

$\ln ($ gross value added $)=-7.08+1.48 * \ln ($ employees $)+0.45 *$

ln (employees productivity)

Results of the econometric analysis are based on software e-views 7 and the results are presented in table 6 .

Table 6. The results of estimated log-linear regression model

\begin{tabular}{|l|l|l|l|l|l|}
\hline ANOVA test & coefficient & Std. Error & $\mathrm{p}$-value & significance & $\mathrm{R}^{2}$ \\
\hline Variable & -7.08 & 2.1 & 0.00 & Significant* & \\
\cline { 1 - 5 } c & 1.48 & 0.1 & 0.00 & Significant* & \multirow{2}{*}{0.99} \\
\hline Number of employees & 0.45 & 0.1 & 0.00 & Significant* & \\
\hline Employee's productivity &
\end{tabular}

* significance at $1 \%, 5 \%, 10 \%$

The parameters are expected to have a positive sign and all the estimated coefficients are highly statistically significant. The slope coefficients can be interpreted as elasticities, specifically elasticity of value added with respect to the number of employees and to 
employee's productivity. A 1 percent change in number of employees, the gross valueadded changes by $1.48 \%$ and 1 percent change in employee's productivity, the production value changes by $0,45 \%$ holding second variable constant.

Graphical representation of the calculated measured values and residual values for this equation is:

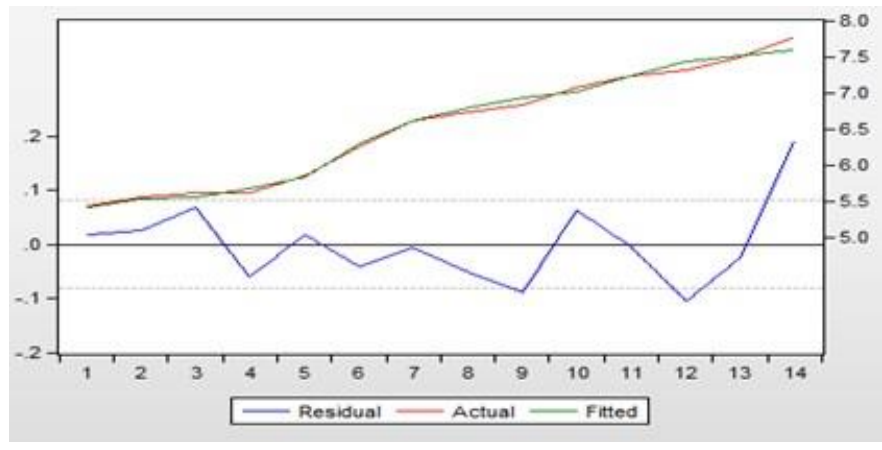

The accuracy of chosen regression model based on current data, is proved by the Fisher statistics (F-statistic), which is significant in results, so model provides a better fit. The quite high coefficient of determination $\left(\mathrm{R}^{2}\right)$ indicates, that model truly represent set of data. So, selected regression model with two explanatory variables, is adequate and about $99,5 \%$ of dependent variable's variance is explained by the selected model.

The Breusch-Godfrey serial correlation LM test and Breusch-Pagan-Godfrey heteroskedasticity test argue that the estimated model has no serial correlation and no heteroskedasticity, Jarque-Bera test indicates normality of residuals (fig. 3).

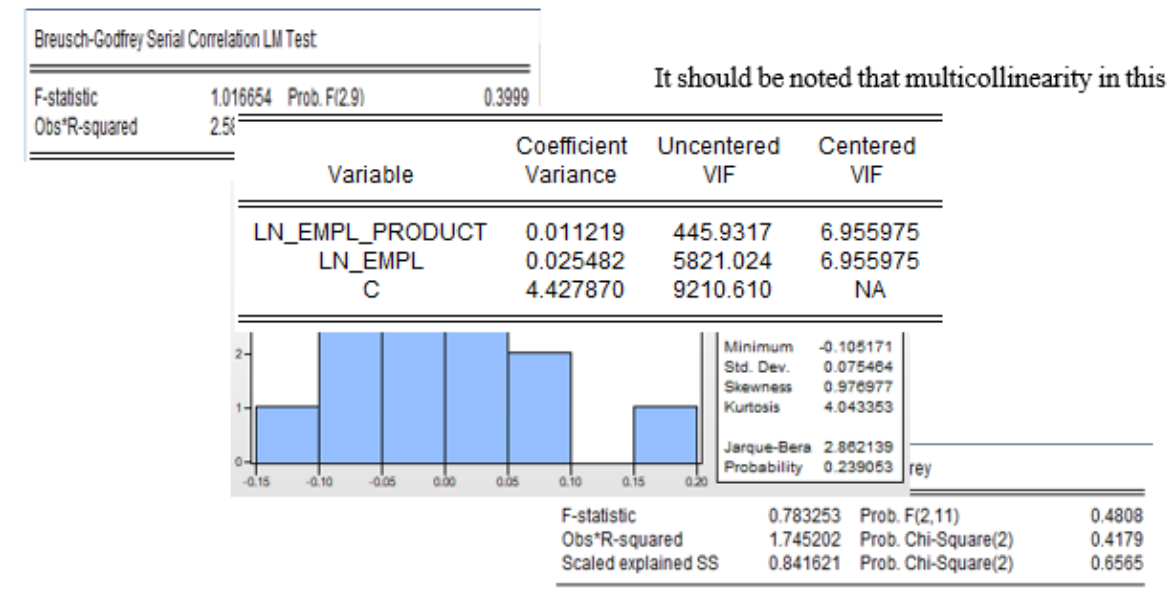

model has not been established (VIF $<10)$.

Fig.3 The results of residual's serial correlation, heteroskedasticity and normality tests

The results of model accuracy and residuals diagnostics tests are presented in table 7 . 
Table 7. The results of model accuracy and residuals diagnostics tests

\begin{tabular}{|c|c|c|}
\hline \multicolumn{3}{|l|}{ Model Specification } \\
\hline $\mathrm{R}^{2}$ & 0.99 & High \\
\hline Adjusted $\mathrm{R}^{2}$ & 0.99 & High \\
\hline $\mathrm{p}$-value (F-statistic) & 0.000000 & Significant \\
\hline \multicolumn{3}{|l|}{ Residuals diagnostics tests } \\
\hline Ho: No serial correlation & Prob. $F(2,9)>0.05$ & Accepted \\
\hline Ho: No heteroskedasticity & Prob. $\mathrm{F}(2,11)>0.05$ & Accepted \\
\hline Ho: residuals are normally distributed & Prob. $>0.05$ & Accepted \\
\hline
\end{tabular}

All econometric analysis was performed according to classical econometric techniques [Wooldridge, 2012].

\section{SME Development Strategy in Adjara A.R.}

In the 2019 regional report "Doing Business 2019" on the World Bank's official web site, presented by European and Asian countries (ECA), Georgia was ranked 6th in the world ranking list, while in 2018 was ranked 9th [Doing...]. The fact is that business development is going on in Georgia, but despite the improvement of entrepreneurial environment, small and medium enterprises has some difficulties in many areas that negatively affect competition. In this regard, much has been written in the works of Georgian researchers, NGO research and projects, as well as in reporting projects with some recommendations. Recommendations relate to the improvement of institutional structure and operating environment of small and medium enterprises, availability of financing of small and medium enterprises, raising entrepreneurial culture, internationalization, introduction of innovations and technologies in small and medium enterprises [OECD...].

"We need a fundamental rethinking of SME and entrepreneurship policies to improve business conditions and access to resources. We need a renewed measurement agenda to understand how countries, regions and cities can capitalize on their many diverse small businesses as drivers for inclusive and sustainable growth" 6 . Despite the impression of the regional development plans, considering that SME development is the source of improvement of the economic environment, several hindering factors impede the development of SME. These problems lay in the utilization of resources and their rational use, as well as in the implementation of SME promotion programs, legislative regulations, etc.

As for the assistance of business in the regions of Georgia, the Ministry of Regional Development and Infrastructure of Georgia developed a Regional Development Program 2018-2021, in which one of the priorities is supporting small and medium enterprises [Regional...].

The initiative of the Government of Georgia is to carry out the state program "Produce Georgia" aimed at facilitating small and medium businesses in regions of Georgia through financial and technical support. In 2015-2018, a total of 596 micro and small

${ }^{6}$ The report at the OECD forum: OECD SME and Entrepreneurship Outlook 2019 
entrepreneurship projects worth up to 5 million GEL were funded within this project in Adjara. In 2016-2019 - in the field of industry - 16 projects, 349 people were employed, in the field of hotel industry - 12 projects, 393 people were employed. [Results of the micro...]

It is written in the Strategic Development Plan of 2016-2021 of the Autonomous Republic of Adjara: "Despite the well-developed financial system and state programs, low availability in the region is on financial resources. Companies enjoy the old technologies and have little opportunities for production. Companies do not have experience in marketing and has problems with producing relevant to existing markets and go to new markets. The reason for this is the low level of business education and qualification of workforce "[Strategic...].

Today small businesses are powerless to independently make radical changes in this regard and improve the situation, thus it has become dependent on state support. Improving the institutional environment of the state is not a sufficient condition for business development. It's needed an effective support policy [Erkomaishvili, 2016]. Recently, support for small and medium-sized businesses has been one of the main directions of both Georgia and the European Union. In the framework of the Association Agreement with the European Union was developed "Small and Medium Entrepreneurship Development Strategy for 2016-2020" [Small...].

UNDP has been assisting the Autonomous Republic of Adjara in the field of local economy and agricultural development since 2008. In 2013-2016, within the framework of the European Agriculture and Rural Development Neighborhood ENPARD, with the support of UNDP, Adjara A.R. in cooperation with the government, a local development program was prepared to support the employment of small farmers and business expansion, a business incubator was established, specialists were trained in various areas, and demonstration plots were planted in Adjara AR.

Within the framework of supporting business activities, Adjara also supports small and medium tourism business programs. Within the same framework there will be launched the program "Successful Ideas", which will be implemented in cooperation with UNDP in 2019 [Adjara Government report 2018-2019].

Adjara has the resource potential to create a favorable business environment for small business development. This is facilitated by its geographical location, natural diversity, etc. Despite the fact that Adjara A.R. With great potential for agriculture, numerous agricultural products are imported. To do this, the government of Adjara should pursue a more active incentive policy for small entrepreneurs.

\section{Conclusions and Policy Implications}

Based on the results of the survey, we can evaluate the contribute of SME to the economic development Adjara A.R., to analyze current economic development of business sector and factors affecting on SME development. For this reason, the research has more practical importance to characteristic the economic situation of the region and to support developing small and medium business. During the research based on data of the National Statistics Office of Georgia and of the Ministry of Finance and Economy of Adjara, statistical significance and validity of the two-factor log-regression model has been 
estimated.

So, in conclusion, estimated model shows that the number of employees and their productivity are significant factors for gross value-added growth. At the other hand, no less important the personnel costs, which includes the remunerations and social assistance of employees. As it helps to estimating productivity costs based on the human capital approach, because the human capital resources and activities creates a gross value added. Behind of labor productivity stands "human capital", i.e., health and skills of employees and other factors, which are important for purpose of policies to support economic growth (for example government programs). In general, the personnel costs define the employee's behavior, stimulus and efficiency. So, the personnel costs representatives the human capital's efficiency. Thus, SMEs are driving job growth, but need higher investment in skills, innovation and tech to boost wages and productivity. In order to increase productivity, resources should be directed towards improving human capital, new technologies in production, and the qualification of the labor force.

Finally, all results of estimates give the formation of following recommendations to support regional business development:

- It is recommended to create additional jobs, with special focus on labor market demandoriented workforce development, so to create more value for the customer and increase the profits of firms by the producing effectiveness.

- Increase the personnel costs like a remuneration and expenses for raising employees' qualifications by the training and education, to support health, cultural and other aspects, and, therefore, to increase the efficiency of employees in producing a goods and services.

- To create a favorable business environment to do "many and well". That means to significantly increase economic growth and the living standards of the population.

- Encouraging entrepreneurship at local and regional level. Lead more active stimulating policy for SM entrepreneurs, promote innovation, stimulating investment, improving access to capital etc.

\section{References}

Acs, Z. and Armington, C., (2002). Economic Growth and Entrepreneurial activity. Center for Economic Studies, U. S. Bureau of the Census, Washington D. C.

Acs, Z.J., Desai, S., Hessels, J. (2008). Entrepreneurship, Economic Development and Institutions. Small Business Economics. Volume 31, Issue 3, pp 219-234. http://cendoc.esan.edu.pe/fulltext/ejournals/Zoltan.pdf / Accessed on 25.11.2019;

Audretsch, D. and Thurik, R., (2002), Linking Entrepreneurship to Growth, OECD STI Working Paper, 2081/2, OECD, Paris.

Baranovsky, A., Tkachenko, N., Glonti, V., Levchenko, V., Bogatyrova, K., Beridze, Z., ... \& Zelenitsa, I. (2020). Non-Price Criteria for the Evaluation of the Tender Offers in Public Procurement of Ukraine. International Journal of Financial Studies, 8(3), 44.

Business sector in Georgia: 2019 / National Statistics Office of Georgia. -Tbilisi, 2019. - 136 p. https://www.geostat.ge/media/28062/Business-sector-2018.pdf /Accessed on: 28.11.2019;

Business sector in Georgia: 2020 / National Statistics Office of Georgia.- Tbilisi, 2020 - 136 p https://www.geostat.ge/media/35014/Krebuli-2020.pdf / Accessed on: 11.12.2020/;

Cobbold, T. 2003, A Comparison of Gross Output and Value-Added Methods of Productivity Estimation, Productivity Commission Research Memorandum, Canberra. https://www.pc.gov.au/research/supporting/comparison-gross-output-value-addedmethods/cgovam.pdf /Accessed 10.12.2020 
Coelli, T. J., Rao, D. S. P., O'Donnell, C. J., and Battese, G. E. (2005). An introduction to efficiency and productivity analysis. 2nd ed. New York, NY, United States: Springer.

Chitanava, N. (2018) Challenges and Strategy of the Georgian Economy. Tbilisi, Publishing House "Iverion"

Doing Business 2019.World Bank Group. Regional Profile Europe and Central Asia (ECA).https://www.doingbusiness.org/content/dam/doingBusiness/media/Profiles/Regional/ DB2019/ECA.pdf / Accessed on 25.11.2019/;

Dvoulety O., Gordievskaya A., Prochazka D. (May, 2018). Investigating the Relationship between Entrepreneurship and Regional Development: Case of Developing Countries, Journal of Global Entrepreneurship Research vol $\quad 8, \quad$ No 16. https://link.springer.com/content/pdf/10.1186\%2Fs40497-018-0103-9.pdf Accessed on: 26.11. 2019/;

Erkomaishvili G. (2016). Small Entrepreneurship Supporting Economic Policy in Georgia.

Glonti, V., Zhiyenbayev, M., \& Manvelidze, R. (2018). The method of estimating the regional budgetary process. In MATEC Web of Conferences (Vol. 212, p. 08029). EDP Sciences.

Glonti, V., Ghoghoberidze, T. and Beridze, Z., 2020. Dynamical Estimation and Prediction of Business Value of Regional Insurance Companies. Economic and Social Development: Book of Proceedings, pp.484-488.

Gvelesiani R. (1999). SME Success Strategy and Culture. "Samshoblo", Tbilisi, p. 143

EU4Business Investing in SMEs in the Eastern Partnership, country report-Georgia, 2019 https://eu4business.eu/files/medias/country report 2019 georgia.pdf

Law on Entrepreneurs. Hegislative Herald of Georgia. https://matsne.gov.ge/ka/document/view/28408?publication=63/Accessed on: 28.11. 2019;

Mekvabishvili E.(2010). Development of small and medium entrepreneurship as the most important condition for the formation of the middle class. http://social-democratsgeorgia.blogspot.com/2010/07/blogpost.html

Monitoring Georgia's SME Development Strategy 2016-2020. OECD Publishing (2019), Paris. http://www.oecd.org/eurasia/competitiveness-programme/eastern-partners/MonitoringGeorgia's-SME-Development-Strategy-2016-2020.pdf / Accessed on: 27.11. 2019/;

Moreno, A. M. and Casillas, J. C., 2008. "Entrepreneurial orientation and growth of SMEs: a causal model". Entrepreneurship Theory and Practice, 32 (3), 507-528.

OECD Eurasia Competitiveness Program. Working Group on SME Development Strategy. Project Report, March 2016. Recommendations for Georgia's SME Development Strategy 2016-2020. http://www.oecd.org/eurasia/competitiveness-programme/easternpartners/Recommendations for Georgia SME strategy.pdf /Accessed on: 25.11. 2019/;

OECD SME and Entrepreneurship Outlook 2019 https://www.oecd-ilibrary.org/sites/34907e9cen/index.html?itemId=/content/publication/34907e9c-en\&mimeType=text/html $/$ Accessed on: 27.11. 2019/;

Papava, V., and M. Tokmazishvili, 2006. "Becoming European. Georgia's Strategy for Joining the EU." Problems of Post Communism, Vol. 53, No. 1.

Regional Development Program of Georgia 2018-2021. Ministry of Regional Development and Infrastructure of Georgia. http://www.mrdi.gov.ge/sites/default/files/2018-2021 regional development programme of georgia unofficial translation.pdf /Accessed on: 27.11. 2019/;

Results of Activity of Enterprises: 2020, III Quarter/ National Statistics Office of Georgia. 04.12.2019 https://www.geostat.ge/media/35150/Activities-of-Enterprises---III-Quarter\%2C-2020.pdf /Accessed on: 11.12. 2020/;

Results of The Micro and Small Business Support Component (October 2019). 12 November 2019. http://www.enterprisegeorgia.gov.ge/en/News/results-of-the-micro-and-small-15 /_/Accessed on: 27.11.2019/;

Rudaz P. (2012). Entrepreneurship in Georgia. Cancasus Analytical Digest. No 45, 15 December, pp. 2-8; https://www.files.ethz.ch/isn/156549/CaucasusAnalyticalDigest45.pdf / Accessed on 26.11.2019;

Schreyer P. and Pilat D. (2001). Measuring Productivity. OECD Economic Studies No. 33 https://www.oecd.org/economy/growth/1959006.pdf

Small and Medium Entrepreneurship Development Strategy 2016-2020.Georgian Government, http://gov.ge/files/439 54422 706524 1001.pdf / /Accessed on 25.11. 2019/; 
Smallbone, D. and Welter, F. (2001), The Role of Government in SME Development in Transition Countries, International Small Business Journal, vol. 19, no. 4, pp. 63-77.

Statistical Yearbook of Georgia: 2019 / National Statistics Office of Georgia. - Tbilisi, 2019. - 290 p. https://www.geostat.ge/media/28915/Yearbook 2019.pdf. / Accessed on: 11.12.2020/;

Strategic Development Plan of Adjara 2016-2021. Ministry of Finance and Economy of Adjara. Project. Batumi.2016. http://adjara.gov.ge/uploads/Docs/acdb5711834a4d0e86f1f4f04e46.pdf / Accessed on: 26.11. 2019/;

Tokmazishvili M. (2010), Promoting the development of small and medium enterprises (development of value growth). In Private Sector and Development: A Series of Discussion Letters, United Nations Development Program.

Tsintsadze, A., Glonti, V., Oniani, L. and Ghoghoberidze, T., 2019. Empirical Analysis of Financial and NonFinancial Risks of the Commercial Bank. European Journal of Sustainable Development, 8(2), pp.101-101.

Wooldridge, J. M. (2012), "Introductory Econometrics". Cengage Learning, 881 p. https://economics.ut.ac.ir/documents/3030266/14100645/Jeffrey M. Wooldridge Introductory Econometrics A Modern Approach 2012.pdf; 